over to another a paper noticing all pre-requisites concerning the affair; and by names of the parents of the intended couple asks a man to pray and divine; and if the presage tells that the union is a lucky one, clothes and ornaments are made for the deceased pair. Now the match-maker goes to the buryingground of the bridegroom and, offering wire and fruits, requests the pair to marry. There two seats are prepared on adjoining positions, either of which having behind it a small banner more than a foot long. Before the ceremony is consecrated by libation, the two banners remain hanging perpendicularly and still; but when the libation is sprinkled and the deceased couple are requested to marry, the banners commence to gradually approach till they touch one another, which shows that they are both glad of the wedlock. However, when one of them dislikes another, it would happen that the banner representing the unwilling party does not move to approach the other banner. In case the couple should die too young to understand the matter a dead man is appointed as a tutor to the male defunct, and some effigies are made to serve as the instructress and maids to the female defunct. ${ }^{1}$ The dead tutor thus nominated is informed of his appointment by a paper offered to him, on which are inscribed his name and age. After the consummation of the marriage the new consorts appear in dreams to their respective parents-in-law. Should this custom be discarded, the unhappy defuncts might do mischief to their negligent relatives. . . . On every occasion of these nuptials both families give some presents to the match-maker ('Kwei-mei'), whose sole business is annually to inspect the newly-deceased couples around his village, and to arrange their weddings to earn his livelihood."

This passage is very interesting, for, besides giving us a faith ful account of the particulars, which nowadays we fail to find elsewhere, it bears testimony to the Tartar, and not Chinese, origin of this practice. The author, Kang Yu.chi, describes himself to have visited his old home in Northern China shortly after its subjugation by the Kin Tartars in II26 A.D.; so there is no doubt that among many institutional novelties then introduced to China by the northern invaders, Marriage of the Dead was so striking that the author did not hesitate to describe it for the first time.

According to a Persian writer, after whom Pétis de Lacroix writes, this custom was adopted by Jenghiz Kân as a means to preserve amity amongst his subjects, it forming the subject of Article XIX. of his Yasa promulgated in 1205 A.D. The same writer adds :- "This custom is still in use amongst the Tartar at this day, but superstition has added more circumstances to it : they throw the contract of marriage into the fire after having drawn some figures on it to represent the persons pretended to be so marry'd, and some forms of beasts; and are persuaded that all this is carried by the smoke to their children, who thereupon marry in the other world" (Pétis de Lacroix, "I History of Genghizcan the Great," trans. P. Aubin, London, I 722, p. 86). As the Chinese author does not speak of the burning of papers in this connection, whereas the Persian writer speaks definitely of its having been added later, it seems that the marriage of the dead had been originally a Tartar custom, with which the well-known Chinese paper-burning was amalgamated subsequently between the reigns of Genghiz and his grandson Kublai--under the latter Marco witnessed the customs already mingled, still, perhaps, mainly prevailing amongst the Tartar descerdants. Kumagusu Minakata.

\section{The Heating of Anodes in X-Ray Tubes.}

IN reply to Mr. Walter Chamberlain's inquiry (p, 198), it must be borne in mind that spark length is not per se a criterion of the energy delivered to a vacuum tube. The length of spark is more or less proportionate to the maximum E.M.F. of the discharge, while the energy of a discharge depends upon the nature of the curves of both E.M.F. and current, and may bear but a small relation to the maximum E.M.F. Large coils which have secondary wire of considerable section and comparatively large electrostatic capacity, give a much greater electric quantity and, consequently, much more energy for each discharge, even when worked so as to give only short sfarks, than do smaller coils the secondary wire of which is of smaller section and capacity.

Röntgen-ray tubes should be excited during exhaustion with a

1 The last clause in original text is doubtful in reading. Perhaps it will be more correct to render it : "And the family of the intended bride provides her with various sorts of utensils and apparel needful to her nurse and mail-servants in the other world." coil of the same dimensions as the one that they are ultimately destined to be worked with. This is a point which does not seem to receive sufficient attention from commercial tube manufacturers.

66 Victoria Street, London, S.W., January I.

\section{Sesamoid Bones.}

JUDGING from a small collection of $\mathrm{X}$-ray photographs made during the year, the female hand seems better provided with sesamoid bones than the male.

In my prints, in the female hand a sesamoid is most often found in the metacarpo-phalangeal joint of the little finger, less frequently in the index : in one case there are two in the interphalangeal joint of the thumb; in this hand, including the two always found in the metacarpo-phalangeal joint of the thumb, there are no less than six sesamoids. In male hands the bones seem to be more evenly divided between the index and fifth fingers. In most cases the sesamoids are larger in the female hand.

December 26,1896

F. J. REIn.

\section{Discharge of Electricity by Phosphorus.}

THE discharging power for electricity of slowly oxidising phosphorus appears to have been known for much longer than Messrs. Elster and Geitel (see p. I 55) seem to be aware of.

In the I 855 edition of the "Encyclopædia Britannica," vol. viii. p. 622, an apparatus is described for collecting atmospheric electricity, first used by Matteucci, in which a piece of phosphorns projecting from a glass tube is connected to an electrometer by a long wire, and exposed to the air whose electrical state is to be investigated. It is said to have been found very useful for this purpose.

Rochdale, December 26, I896.

\section{Shooting-stars observed on January 2.}

THis morning, between six and seven o'clock, there has been a very unusual number of shooting-stars. The radiant point was somewhere near Corona. I saw, on the whole, two or three dozen. The brightest was not much inferior to Jupiter. Sheffield, January 2.

H. C. SORBr.

\section{THE GEODETTC SURVEY OF SOUTH $A F R I C A{ }^{1}$}

THE Report on the Geodetic Survey of South Africa, presented to both Houses of the Cape Parliament, and printed in Blue-book form, is interesting and important. It is a record of geodetic work well planned and ably carried out, and it has a permanent value, not only from a scientific point of view, but as an accurate basis upon which all future surveys of the country may be confidently founded.

Soon after his appointment as H.M.'s Astronomer at the Cape in 1879 , Dr. Gill recommended that a geodetic survey should be commenced, and formulated a scheme "for a gridiron system of chains of principal triangulation extending over the Cape Colony, the Orange Free State, Natal, and the Transvaal." His recommendations were cordially supported by Sir Bartle Frere and Sir George Colley, then respectively Governors of the Cape Colony and Natal ; but it was not until June 1883 that the work was fairly commenced, by the measurement of a baseline in Natal. On the completion of this operation, severe pressure was applied by the Government of Natal to accelerate the work at the expense of accuracy; and on two subsequent occasions the question of suspending the survey was seriously considered. It was no easy task to convince Governors and Ministers that true economy lay in "basing all future surveys upon a principal triangulation of such accuracy, that its results might be

1 " Report on the Geodetic Survey of South Africa." Executed by Litut. Colonel Morris, R.E., C.M.G., under the direction of David Gill, H.M. Astronomer at the Cape. Parliamentary Paper. Pp. xii +291 . (Cine Town: Richards, 1896 .)

No. 1439 , VOL. 55$]$ 